\title{
Sobre o anarquivamento - um encadeamento a partir de Walter Benjamin
}

Márcio Seligmann-Silva*

\begin{abstract}
RESUMO: O artigo faz uma análise de uma série de obras de arte, sobretudo feitas após a Segunda Guerra Mundial, como uma tentativa de propor a figura do arquivo como uma chave para organizarmos o que se passa na nossa cultura hoje. No século XX o derretimento do arquivo central da razão ocidental serviu para desencadear um trabalho de rememoração e recoleção dos arquivos. A virada biológica entronizou a noção de herança genética e de processo de reinscrição de arquivos herdados. Já a virada cibernética generalizou discursos sobre memórias, arquivos, gravação e apagamento de informações. Os artistas, nessa paisagem, vêm pensando, desde o romantismo, contra-estratégias diante da arquivação e arquivonomia monológicas: eles se tornaram anarquivadores.
\end{abstract}

PALAVRAS-CHAVE: anarquivamento, cultura como arquivo, coleção

\footnotetext{
* Márcio Seligmann-Silva é doutor pela Universidade Livre de Berlim, pós-doutor por Yale e professor titular de Teoria Literária na UNICAMP. É autor de, entre outras obras, Ler o Livro do Mundo (lluminuras, 1999), Adorno (PubliFolha, 2003), O Local da Diferença (Editora 34, 2005), Para uma crítica da compaixão (Lumme Editor, 2009) e A atualidade de Walter Benjamin e de Theodor W. Adorno (Editora Civilização Brasileira, 2009). Foi professor visitante em Universidades no Brasil, Argentina, Alemanha e México. E-mail: marcioseligmann@me.com
} 
ABSTRACT: The article makes an analyses of a series of artworks, especially those made after de Second World War, as a way to propose the archive as a key idea to understand what happens with our culture today. In the 20th century the melting process of the central archive of the western though opened a period of recollection of the archives. The biological turn has enthroned the notion of genetic inheritance and of reinstatement of the inherited archives. On the other hand, the cybernetic turn has generalized speeches about memories, archives, recording, erasing, and deleting information. Many artists, in this landscape, since the Romanticism, have been developing combat strategies against the monological procedures of archiving and of the archival science: they became anarchivists.

KEYWORDS: anarchivation, culture as archive, collection

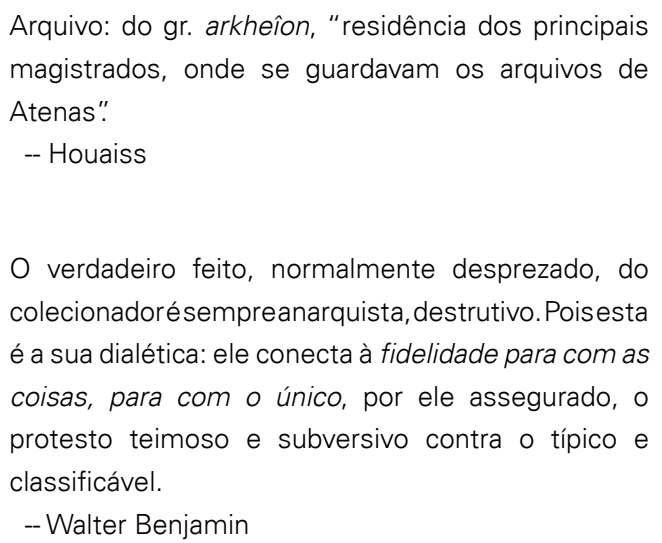

A arquivonomia, ou seja, a doutrina que trata da organização e administração de arquivos, é um saber que remonta às origens do que poderíamos chamar de nosso processo de humanização. Nosso nómos é a lei do arquivamento. Nosso "grito originário de nascimento", provavelmente um grito de horror (diante de nosso desamparo e medo diante do "outro"), que nos separou da natureza, estabeleceu a primeira linha organizatória. Desde então apenas nos enredamos cada vez mais em arquivos e em códigos. Ao menos é assim que, hoje, na era do "mal de arquivo" (Derrida), passamos a ver e ler a nossa história. Desse ponto de vista, as 
primeiras inscrições rupestres e traçamentos sobre o corpo, sobre flechas e tabletes de argila já seriam protoescrituras que tentavam organizar o mundo em "pastas" - files, arquivos. Dos tabletes aos tablets, como na cena de abertura de 2001, Uma odisseia no Espaço de Kubrick, foi só um pulo. Traçar, afinal, significa estabelecer fronteiras, criar limites, construir identidades, reivindicar a posse e o poder. Os atos sacrificiais, como Marcel Mauss (1999) apontou, são rituais de comunicação com o mundo dos deuses, ritos de passagem e de demarcação das fronteiras entre o nosso mundo e o além. Qualquer erro nessa comunicação, qualquer poluição do nosso mundo pelas forças divinas, pode provocar as mais terríveis catástrofes. Os mitos, os deuses no panteão clássico, os santos católicos em seus nichos nas igrejas, as representações da paixão de Cristo: tudo isso nós aprendemos também a ler como uma longa história da construção e transmissão de arquivos. Para escrever este artigo eu tive que consultar livros, meus arquivos fotográficos, arquivos de textos e diversos arquivos on-line. Este texto mesmo faz parte de um novo arquivo que por sua vez poderá vir a se desdobrar, em forma de reprodução ou de citações, em outros arquivos analógicos ou digitais.

\section{Pequena arqueologia do arquivo}

Ao longo do século XX a humanidade foi submetida a uma espécie de desdobramento paroxístico do Esclarecimento (Aufklärung) e de sua terrível dialética: ao invés do prometido triunfo de uma vida civilizada, racional e livre das peias da incivilização, o processo civilizatório se mostrou violento, genocida, amigo da guerra e da destruição. Nunca um número tão grande de seres humanos foi executado em guerras ou por meios tão terríveis e vis como os campos de concentração e de extermínio, como ocorreu no século XX. A razão ocidental, esse constructo que levava em si um arquivo que era constantemente redesenhado e cujas origens também foram projetadas, desde o Renascimento, na Grécia antiga, foi derretida sob o calor dessas catástrofes. O abalo no arquivo central do Esclarecimento levou a uma disseminação dos saberes. Trata-se do conhecido "fim das grandes narrativas", não só no sentido benjaminiano, da morte do narrador, mas também da morte dos grandes discursos que procuravam dar sentido (um sentido nomológico) à humanidade e à sua história e devir. Ao invés da fé cega na razão e na sua capacidade de revelar a verdade, surge cada vez mais ao longo da modernidade um outro modo de pensar e de agir que desconfia dos arquivos. 
Esse contramovimento é o que convencionalmente denominamos de romantismo, ou seja, ele já estava sendo gestado desde o início do século XIX como resposta aos seus arquivos e excessos da razão esclarecida (colonialista, exploradora da mão de obra escrava ou operária, homofóbica, feminicida e com sede de sangue). No bojo do romantismo, artistas levantaram-se em revolta contra a ação da norma e sua tendência a reduzir tudo ao(s) arquivo(s) do poder. Artistas se tornam cada vez mais anarquivadores, anarquizadores do arquivo. Assim, por exemplo, Goya, com seus Los desastres de la guerra, de 1810-15, vai fazer uma inscrição a contrapelo do que foi a Guerra de Independência Espanhola, revelando sua violência crua. Baudelaire e outros escritores vão pensar a nova subjetividade moderna, as paixões, a sexualidade, as novas experiências táteis e os medos desse novo ser citadino que surge então, marcado pela necessidade de se vender ao mercado para sobreviver.

As vanguardas artísticas do início do século XX desarquivam toda a história da arte. Elas procuraram abrir o arquivo das artes para novas formas de percepção e configuração. Aos pouco vão também abrindo o arquivo ocidental a um diálogo (às vezes neocolonialista, mas nem sempre) com outras tradições, da África e do oriente. Novos traçamentos são feitos, apagam-se fronteiras - e outras são estabelecidas. O abalo da Segunda Guerra Mundial pulveriza as próprias vanguardas. Microarquivos e micro arquivonomias vão ser ensaiadas. Em 1953 foi feita uma descoberta que coroou um século de darwinismo, no qual os cientistas não conseguiam esclarecer o mistério de hereditariedade das informações genéticas. A estrutura do DNA foi descrita e a descrição dessas peças primárias, primeiros componentes da escrita do ser e de sua história, serviu também para generalizar a consciência de que a vida, como a cultura, é a história de arquivos, de suas reescrituras e de suas metamorfoses.

\section{Arte e anarquivamento}

As artes a partir desse momento vão cada vez mais adotar a figura do arquivo para si. Mas, seguindo a tendência romântica acima referida de anarquivamento, os artistas vão embaralhar os arquivos, vão pôr em questão as fronteiras, vão tentar abalar poderes, revelar segredos, reverter dicotomias, para as explodir. A palavra de ordem é anarquivar para recolecionar as ruínas dos arquivos e reconstruí-las de forma crítica. O artista se assume como demiurgo, mas não mais como participante submisso, como queriam os fascismos e totalitarismos do século 
$X X$, que tentaram submeter as artes a projetos megalomaníacos de arquivamento da sociedade e de seus indivíduos. Esses movimentos falharam justamente porque fechavam de modo ditatorial os arquivos e a arquivonomia. Eles culminaram em arquivos mortos. Literalmente, como em Auschwitz, no Gulag, no Vietnã sob o Khmer Vermelho etc.

O artista quer destruir esses arquivos que funcionam como máquinas identitárias de destruição (pois eliminam os que são diferentes do "tipo"). Daí, por exemplo, no Brasil termos reconhecido na obra de Bispo do Rosário uma potente representante da arte contemporânea. Bispo desloca os arquivos. Como alguém que provém de uma tripla exclusão: negro, pobre e "louco" (além de ser do "terceiro-mundo"), ele representa de modo radical a figura do artista como anarquivador. Ele pode ser entendido na tradição daquele trapeiro, descrito por Baudelaire. A descrição que este fez do trapeiro deve ser posta lado a lado da figura urbana moderna do trabalho do próprio poeta e do artista:

Aqui temos um homem - ele tem de recolher na capital o lixo do dia que passou. Tudo o que a cidade grande jogou fora, tudo o que ela perdeu, tudo o que desprezou, tudo o que destruiu, é reunido e registrado por ele. Compila os anais da devassidão, o cafarnaum da escória; separa as coisas, faz uma seleção inteligente; procede como um avarento com seu tesouro e se detém no entulho que, entre as maxilas da deusa indústria, vai adotar a forma de objetos úteis ou agradáveis. (Apud BENJAMIN, 1989, p. 78) ${ }^{1}$

O próprio Benjamin, que cita essas palavras de Baudelaire, não apenas foi um teórico da coleção e do colecionismo (lembremos de seu conhecido ensaio sobre Eduard Fuchs, um dos maiores colecionadores de ilustrações eróticas e de caricaturas da modernidade), mas ele mesmo colecionou livros infantis e de "doentes mentais", bem como brinquedos, como lemos nos seus Diários de Moscou. Seu texto de 1931 Ich packe meine Bibliothek aus. Eine Rede über das Sammeln (Desempacotando minha biblioteca. Um discurso sobre o colecionar) reúne muitas de suas reflexões sobre esta prática. Ele vê no ato de colecionar livros antigos - marcado pela pulsão "infantil" do colecionar que renova o mundo via uma pequena intervenção nos objetos - uma espécie de renascimento das obras. ${ }^{2}$ Estas ideias podem nos ajudar a pensar o universo de Bispo, como autor de uma coleção onde o mundo se renova, renasce, sob a batuta do colecionismo. Uma das ideias seminais de Benjamin sobre a coleção pode ser lida no seu texto "Lob der Puppe" ("Elogio da boneca"), que trata justamente de um ponto vital do gesto do colecionador: a relação entre o indivíduo (que seleciona, arranca 
do contexto e coleciona) e o mundo objetivo das "coisas". "O verdadeiro feito, normalmente desprezado, do colecionador é sempre anarquista, destrutivo. Pois esta é a sua dialética: ele conecta à fidelidade para com as coisas, para com o único, por ele assegurado, o protesto teimoso e subversivo contra o típico e classificável." (BENJAMIN, 1972, p. 216; eu grifo) Bispo, o "louco", classificado com uma série de etiquetas psiquiátricas que o desclassificaram da vida extramuros, reconstrói o mundo com seu colecionismo, organiza seu universo sob o signo de uma tipologia que estranha o mundo que o estranha. Ele salva o momento individual de cada coisa, rompendo com os falsos contextos e subsunções aos conceitos abstratos. Sua atração pelo universo dos concursos de miss (que classifica a beleza segundo potentes tipos, normalmente opostos aos biótipos dos companheiros de internato de Bispo e dele próprio), pode ser lida como um desejo de se confrontar com a terrível ontotipologia que o excluía do glamour de uma sociedade "higienizada" de negros e de "loucos". Sua vontade de anarquivar e recolecionar objetos pode ser interpretada como um fruto de sua fidelidade visceral aos cacos do mundo que se lhe apresentavam como única realidade, única possibilidade de construção de uma "casa" onde morar. Sua arqueologia é decorrente de sua anarquivação do mundo. Ele deslouca os arquivos e os recria na sua arte.

\section{A nova arte da memória}

Outra artista que explora de modo crítico e muito criativo a figura do arquivo é Rosângela Rennó. Ela se diz especialista em "esquecimento", não em memória. E de fato, suas imagens são imagens do esquecimento: ela coleciona o que estava no arquivo morto de uma sociedade que prefere, como a sociedade brasileira, esconder sua história de violência e de opressão. Em Imemorial, por exemplo, Rennó realizou, em 1994, um impactante trabalho de memória e de tentativa de escovar a história a contrapelo. Nessa obra, ela reuniu 50 fotografias a partir de um enorme arquivo abandonado que ela encontrou no Arquivo Público do Distrito Federal referente à construção de Brasília. Sabe-se que inúmeros trabalhadores, os chamados "candangos", morreram de modo trágico durante a construção de Brasília, que pontuou o governo do presidente Juscelino Kubitschek: uma cidade construída em menos de 4 anos, com exploração abusiva dos trabalhadores (com jornadas de 14 a 18 horas) e repressão à bala das suas tentativas de organização e revolta. A apresentação do trabalho de Rennó é uma homenagem aos mortos, sendo que as fotos, ampliações de fotos deterioradas $3 \times 4$ encontradas no arquivo 
abandonado e esquecido, apresentam uma forte ambiguidade, oscilando entre as imagens de cerimônias oficiais de recordação e o esquecimento das vítimas anônimas do "progresso" e da "civilização". O título Imemorial faz lembrar o conceito de counter monument, que passou a ser empregado nessa mesma época por teóricos da memória da Shoah como James Young. Essas expressões remetem à aporia contida em todo ato de recordação de eventos traumáticos, que é agravada conforme a dimensão e intensidade da catástrofe que originou o trauma. No caso de Imemorial trata-se de iluminar o outro lado da ideologia desenvolvimentista, do culto cego ao progresso, de mostrar a falsidade da utopia-Brasília, que significou a morte de "candangos", bem como a expulsão dos pobres para as cidades satélite. Rennó nos faz ver o lado distópico daquela capital, ironizando, ao mesmo tempo, de modo crítico, os rituais e memoriais oficiais (arquivos, estes sim, mortos). Como nos trabalhos de artistas vinculados ao antimonumento, como Jochen Gertz e Horst Hoheisel, Rennó, por meio de inversões, nos faz ver o esquecido, o socialmente recalcado: no caso, os trabalhadores mortos que ficaram enterrados nos alicerces da capital, macabras pedras fundamentais sem nome, em cujos protocolos consta apenas a frase cínica: "dispensado por motivo de morte". Seu contra-arquivo serve de antídoto ao esquecimento e revela em que medida não podemos separar mais os termos arte, política e ética da memória.

A memória só existe no presente, mas o artista trabalha com a multiplicidade de tempos e gerações envolvidos no seu trabalho de arqueólogo. Outro exemplo da América Latina, diretamente ligado ao drama de suas ditaduras, vemos em um trabalho do fotógrafo e artista argentino Marcelo Brodsky. Em sua exposição e no catálogo Nexo ${ }^{3}$ vemos uma obra que consiste nas fotos de livros que haviam sido enterrados durante a ditadura argentina na casa de Nélida Valdez e Oscar Elissamburu, em Mar Del Plata. Estas obras desenterradas aparecem sobre a terra desgastadas pela umidade, como um arquivo que teve que ser escondido e que, após o fim da ditadura, puderam ser reveladas à luz do dia. Entre esses livros está o volume Condenados de la terra, de Franz Fanon, que faz lembrar de outros lugares de memória, das lutas anticolonialistas, mas também, com seu nome, leva a pensar nestes livros que foram condenados a ficar sob a terra, em um esquecimento imposto. Esses livros ficaram em uma tumba, sendo que, ao mesmo tempo, o sepultamento foi negado aos mais de 30.000 desaparecidos durante o regime militar argentino. Marcelo Brodsky, em suas obras, desconstrói as criptas do terror na ditadura argentina. (SELIGMANN-SILVA, 2009) 
3005
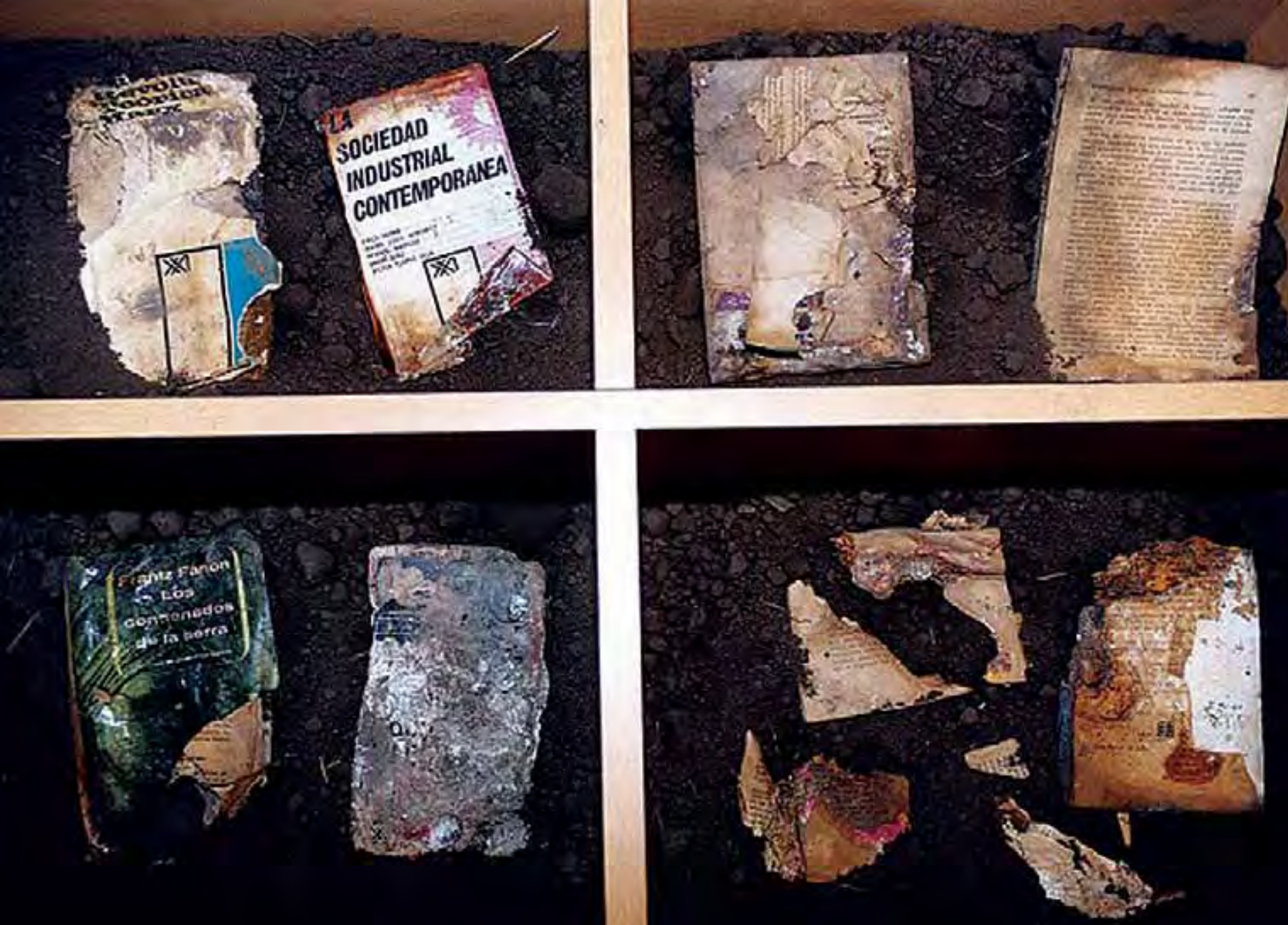

\section{Marcelo Brodsky}

Los Condenados de la Tierra, 1999.

madeira, terra e papel, $60 \times 85 \times 15 \mathrm{~cm}$ 
Essa estética do acúmulo, da metonímia e não da metáfora, é típica da arte da rememoração do terror. Ela nos remete de imediato para a ideia de (an)arquivo. Anos antes de Brodsky, entre 1956 e 1964, Joseph Beuys idealizou uma obra denominada de Auschwitz Vitrine, que consistia em uma caixa de vidro contendo uma série de materiais acumulados, colecionados, como se fossem restos daquele local de memória contido no título da obra: arame-farpado, eletrodos, sebo, mapas de campos de concentração, vidros cilíndricos, massa em forma de salame. A estética dessa obra tornou-se, como sabemos, característica na arte das últimas décadas do século XX e ainda marca as atuais exposições de arte contemporânea. Na vitrine, um arquivo aberto e público, o artista recoleciona fragmentos do (seu) mundo, em uma verdadeira reinvenção da "écriture du soi", no sentido que Foucault (2004) deu a esse termo a partir dos filósofos estoicos e cínicos. Essa escrita costura entre o público e o privado, quebrando barreiras e fronteiras, servindo para reconstruir nossas tênues identidades.

Em Biron, uma pequena cidade francesa marcada pelas duas guerras mundiais, o artista alemão Jochen Gerz recebeu a encomenda de fazer uma obra para substituir o antigo obelisco aos mortos da cidade, que estava quebrado. Contudo, ao invés de substituí-lo, ele realizou um questionário envolvendo toda população do vilarejo, no qual perguntava o que seria para os habitantes de Biron tão importante a ponto de valer pôr em risco suas próprias vidas. As respostas foram posteriormente gravadas de modo fragmentário e anônimo (em um espaço equivalente a sete linhas para cada uma), em plaquetas (tabletes, novamente) que foram fixadas no obelisco e no seu pedestal. A ideia é que esse "monumento" continue em perpétuo devir. Gerz não apenas integrou o monumento antigo na cidade, mas o próprio processo de recordação. "Nós apenas nos recordamos daquilo que nós nos esquecemos" (GERZ, 1996. p. 9), afirma o artista. Com essa obra, Gerz desarquiva a memória heroica a favor de um genuíno trabalho de rememoração no presente e de reavaliação dos valores éticos. Além disso, em suas obras, essa arte da memória dá continuidade à antiga mnemotécnica clássica, ao entrelaçar o culto dos mortos, as escrituras verbal e visual e o procedimento de fazer "listas" de nomes. "No final das contas, tudo que fica são listas, listings" (GERZ, 1995, p. 154), disse ele também. Esses arquivos em forma de lista também podem ser lidos em inúmeros memoriais, deixados no rastro do século XX, como o famoso monumento aos soldados mortos na guerra do Vietnam, feito pela arquiteta Maya Lin em Washington, ou, mais recentemente, no memorial erigido aos desaparecidos da ditadura argentina, no Parque de la Memoria, em Buenos Aires. Também em Buenos Aires, Marcelo Brodsky fez uma placa denominada “Lugares de Memoria 
que no debemos olvidar jamás", que contém a lista dos campos argentinos onde prisioneiros políticos foram presos, torturados e desaparecidos. Esse trabalho, por sua vez, foi inspirado em uma placa idêntica, em Berlim, com o dizer "Orte des Schreckens, die wir niemals vergessen dürfen" ("Locais do terror dos quais nós nunca devemos nos esquecer") seguido da lista de campos de extermínio e de concentração nazistas. A memória é tratada aqui como uma lei: "não esquecereis". Contra o esquecimento o artista coleciona e lista locais de terror.

Poderia ainda lembrar da arte da memória e anarquivista de outros artistas contemporâneos como Naomi Tereza Salmon (autora de uma série de fotos de restos de campos de concentração nazista, reproduzida em um catálogo em formato de pasta-arquivo: Asservate. Exhibits. Auschwitz, Buchenwald, Yad Vashem), Christian Boltanski, Cindy Sherman, Horst Hoheisel, Andreas Knitz, Micha Ullman, Anselm Kiefer e Daniel Libeskind. Cada um deles desenvolveu uma poética própria, onde a memória desempenha um papel de polo aglutinador e as artes fazem jus ao fato de serem filhas de Mnemosine. Nas obras desses autores, algumas das principais caraterísticas da arte da memória contemporânea e de seu procedimento de anarquivamento vêm à tona.

\section{Artes do corpo-arquivo}

Assim como essa nova arte da memória, também as artes do corpo reatualizam a figura do arquivo. Os trabalhos que tratam especificamente do corpo, como os de Sherman, as fotos de Zanele Muholi (que documenta mulheres lésbicas e transgênero na África do Sul) e as de Nan Goldin vão embaralhar diversos arquivos. Muholi e Nan Goldin expõem para a esfera pública em suas fotos a intimidade e aspectos da vida privada e da sexualidade. Ao publicizar o drama da AIDS ou a relação da mulher com seu corpo, temas que antes seriam considerados menores e restritos à esfera íntima, ganham a dimensão de questões políticas prementes. Essa abertura do arquivo da intimidade, de resto, foi encenada de modo literal por Annie Sprinkle, que no início dos anos 1990 fazia uma performance que consistia em ficar sentada de pernas abertas e permitir que o público olhasse através de um tubo que terminava em sua vagina. Novas fronteiras identitárias são delineadas com essas quebras de tabu.

Já Hans Eijkelboom fotografa citadinos em grandes metrópoles e os rearquiva mostrando a regularidade e homogeneidade de suas roupas. Sucumbimos sob a ditadura da mesmice da moda e Eijkelboom denuncia isso com seus arquivos fotográficos que tendem ao infinito da 
mesmice. A moda parece oferecer de modo paradoxal a unicidade, a singularidade ao lado da promesse de bonheur do mergulho no "todo", no "absoluto" da fusão com a massa, na qual todos são idênticos.

Jake and Dinos Chapman, por sua vez, em obras como Zygotic Acceleration, Biogenetic, Desublimated, Libidinal Model, fundem diversos corpos nus, cujas faces estão desfiguradas pela presença de órgãos genitais. O corpo é apresentado como arquivo que é redesenhado revelando nossas pulsões e anarquivando uma longa e, hoje, opressiva história da construção do corpo clássico, sem máculas e dessexualizado. Patricia Piccinini, em obras como The Young Family, hibridiza o corpo humano e o animal, rompendo a barreira entre a animalidade e a humanidade e apontando para desdobramentos possíveis da biogenética. Essa quebra da fronteira entre o arquivo animal e o humano tem uma longa história, na qual consta não só a figura judaica, mítica, do Golem, como também filosofemas de Descartes, o sonho do homem-relógio por Julien Offray de la Mettrie em seu tratado L'homme machine, de 1748, Mary Shelley e seu Frankenstein, o Moderno Prometeu, de 1818, H.G. Wells e seu The Island of Dr. Moreau, de 1896, ou seja, já em plena era de Darwin, mas ainda antes da quebra do segredo do código do DNA. Nossa "crise de identidade", do nosso arquivo-corpo, culmina na superação das polaridades natureza-cultura, animal-humano, que gera euforia e angústia. As artes são potentes meios de autorreflexão sobre essa nossa deriva corpórea e, junto dela, as ficções científicas (seja na forma de romances ou de filmes) devem ser levadas a sério como gênero que permite penetrar em nossos sonhos e pesadelos nascidos dessas novas possibilidades que a técnica abre ao nosso corpo.

\section{Documenta e Bienais: mega-arquivos ambíguos}

A Documenta de Kassel e as bienais de arte espalhadas pelo mundo tornaram-se eventos midiáticos de primeira ordem em um mundo que tende para a estetização e autoencenação espetacularizada de si. Os curadores são agora artistas de segunda ordem que fazem suas recoleções e seus mega-arquivos. Existe uma tendência a incorporar nesses mega-arquivos algo do gesto do anarquivamento, mas isso nem sempre é bem sucedido, dadas as imposições comerciais e até políticas a que grandes exposições como essas estão submetidas. Mas essas curadorias acabam refletindo algumas das grandes linhas de força de sua época 
e os temas do arquivo, da coleção e da memória têm ocupado boa parte dessas exposições.

Também a Documenta 12, de 2007, com curadoria de Roger Buergel, teve a coleção e o arquivo como temas centrais. A imagem que serviu de umbral e de mote da exposição foi a famosa pintura de Klee, Angelus Novus, que pertenceu a Walter Benjamin e inspirou sua não menos famosa tese sobre o conceito de história, que resume, em uma imagem icônica, a concepção barroca da história que foi reatualizada no século XX por conta de seu acumulo de violência. ${ }^{4}$ Dessa imagem deriva a ideia da história como acúmulo de escombros e ruínas que devem ser recolecionados tendo em vista a redenção após a catástrofe. É daqui, portanto, que podemos derivar também a imagem do arquivo e do anarquivamento: o trabalho de recordação agindo como esse anarquivamento, que arranca determinados momentos de seu falso contexto (a falsa totalidade), para resignificá-los nesse ato de recriação.

Uma obra espantosa nessa Documenta era o The Zoo Story, do austríaco Peter Friedl. O obra consiste em uma girafa empalhada, na verdade, "mal empalhada", dando a impressão que a pele é uma "roupa" grande demais. Essa técnica faz lembrar dos museus de história natural, com sua história que remonta ao século XVII, paralela ao desenvolvimento da taxinomia. Mas Friedl não está lidando com o arquivamento biológico da girafa, mas sim com esta girafa em específico que ele apresenta e sua história. Este animal único, salvo pelo artista na forma de cadáver empalhado, representa o documento de uma barbárie, a saber, a violência do exército israelense na cidade de Qalqilyah, na Cisjordânia, que provocou a morte de vários animais do zoológico local. A girafa Brownie, ao lado outros animais, mortos no dia 19 de agosto de 2002, foram empalhados e expostos em uma ala especial do Zoo de Qalqilyah. O que Friedl fez ao transladar Brownie para Kassel foi um anarquivamento que põe em destaque uma dupla violência: contra os habitantes da Cisjordânia e contra os animais, não só presos em zoológicos, mas também aí executados. Essa story é também uma narrativa que pode ser encadeada em uma longa história da circulação de girafas e de seu significado político. A primeira girafa viva a pisar no território alemão, em 1220, foi apenas uma das antecessoras de Brownie. 0 colonialismo e suas mil histórias de violência podem ser desdobradas e anarquivadas a partir dessa figura zoomórfica.

Por sua vez, a série de painéis fotográficos da nova-iorquina Zoe Leonard (1961, NY), Analogue (1998-2007), funciona como uma espécie de mapeamento da globalização. O título indica 
também a passagem da fotografia analógica para a digital, como se nesse mundo globalizado não houvesse mais as distâncias e diferenças que marcavam o mundo pré-globalização e analógico. Ao invés de se falar em era pós-aurática, agora o tema é o pós-analógico - contemporâneo ao fim das utopias e das grandes narrativas. Se Benjamin pôde ver nas passagens parisienses concentrados paradigmáticos do século XIX e de seu culto da mercadoria (com sua força de fetiche), agora vemos que o mundo se transformou em uma enorme galeria, uma "passagem" na qual vitrines sem fim reproduzem os mesmos objetos. De modo ambíguo, esses objetos perdem seu valor de sedução e são investidos de um ar de decadência, de mercadoria abandonada, empoeirada e kitsch. Justamente nessa época em que Leonard fez Analogue, os arquivos são entronizados como modelos nas artes. Essas fotos são como arcas, depósitos, que arquivam o estado do mundo em uma época digital, na qual tudo perde seu contorno e identidade muito mais rapidamente que no final do século XIX, quando Atget documentava a Paris em desaparecimento sob o impacto das reformas de Haussmann. Vemos coleções de fachadas de casas, de vitrines, fotografias de fotografias, fotos de mercadorias etc., tudo arranjado como um catálogo do mundo, sem fronteiras e "sem chão." As mercadorias circulam de país em país e são recicladas em uma cadeia que reproduz a exploração de modo quase conformista, como se não houvesse saída desse círculo analógico. As analogias que são estabelecidas por certos motivos que se repetem, como a reprodução de bandeiras norte-americanas em roupas, aponta também para um processo de homogeneização e massificação. No limite, a diferença é insignificante. Processo semelhante pode ser visto também nos painéis de Eijkelboom que vimos acima. Na medida em que Leonard faz muitas fotos de objetos por detrás de vidros e molduras, ao fotografarmos seus arquivos, ou seja, seus painéis fotográficos apresentados eles também por detrás de vidros, estamos repetindo seu gesto e entrando nessa cadeia analógica que também rompe as fronteiras entre o dentro e o fora do campo artístico. Este se revela como parte desse "circular estático" de mercadorias que ela documenta.

Outra obra da Documenta 12 também se revela muito apropriada para pensarmos o tema do arquivo. Refiro-me ao trabalho Top Secret (12.1989-02.1990) de Nedko Solakov (1957, Bulgária). A obra tem a forma de um pequeno arquivo de madeira com duas gavetas cheias de fichas preenchidas. Essas fichas contém a descrição de denúncias feitas pelo próprio artista às autoridades comunistas da Bulgária, nas quais ele relatava acerca do comportamento de outros 


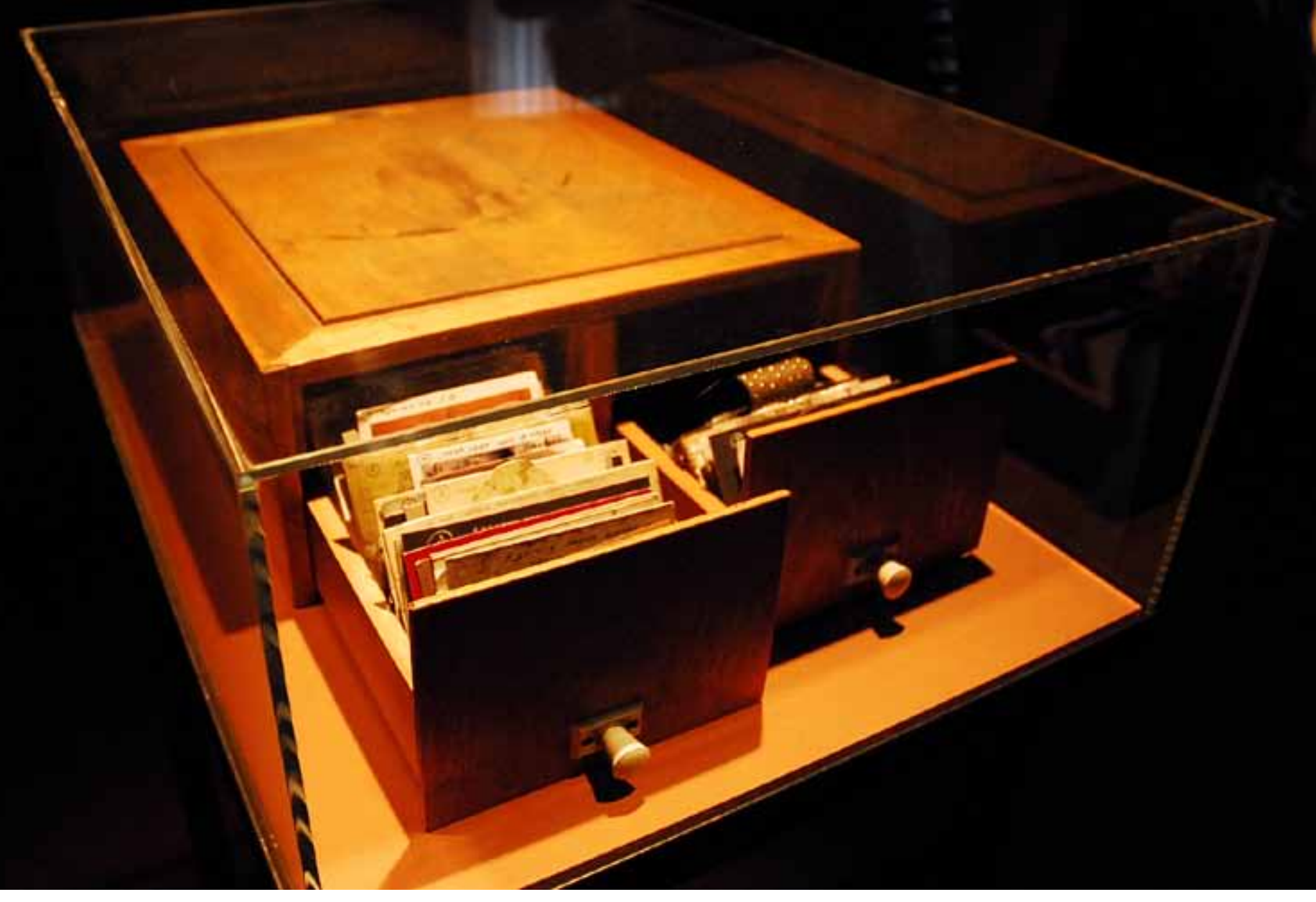

Nedko Solakov

Top Secret, 1989-90.

(Foto: Marcio Seligmann-Silva) 
artistas. Solakov fez essa obra como parte de um trabalho seu de elaboração dessa participação no sistema de delação que marcou o regime totalitário no qual cresceu e do qual fez parte como informante. Quando ele realizou essa obra, ele já havia rompido há anos com essa prática de delação e já era visto com desconfiança pelas autoridades. Ao abrir seu arquivo privado, como meio de elaboração de sua culpa, ele fez um gesto duplo de écriture de soi, ou seja, de ego-escrita como meio de reconstrução de si, e também como um ato público e político de denúncia do que o sistema totalitária fazia com as pessoas, ou seja, as transformavam em peças massificadas de um sistema. Ao tornar público esse arquivo, Solakov abalava tanto seu arquivo privado (revelado como meio de confissão e esperada catarse do seu trauma) como os arquivos da polícia secreta comunista: que apenas vieram a se tornar públicos na Bulgária recentemente, em 2011, ou seja, 22 anos após o fim do regime comunista e dessa obra de Solakov. Ele tornara-se uma personagem suspeita a partir de 1983, quando decidira não mais cooperar com o serviço secreto. Ao expor sua obra em 1990, por sua vez, ele se tornou suspeito por parte de uma sociedade que passou a perseguir os antigos colaboradores. Seu gesto de autoexposição deve ser visto como um ato de coragem, de enfretamento de suas contradições e das contradições de uma sociedade em torno de seus "arquivos secretos".

O Estado moderno sempre necessitou estabelecer as fronteiras entre o secreto e o não-secreto. A lei do arquivo decreta o seu ser secreto. O arquivo secreto é uma necessidade do Estado e de toda estrutura de poder - contra eles se volta o anarquivamento que o campo artístico ainda propicia. Essa obra de Solakov, ao lado de tantas outras que apresentam os arquivos secretos e pessoais dos artista, representa uma revolta contra essa tendência totalitária. Solakov, com seu arquivo, nos faz lembrar também de uma era analógica de arquivos que está sendo deixada para trás, mas que ainda não está morta. O drama atual no Brasil em busca dos arquivos secretos da ditadura é uma prova disso. Se na Bulgária levaram 22 anos para a abertura dos arquivos, no Brasil, em 28 anos após o fim da ditadura civil-militar ainda não chegou-se lá.

O impulso de arquivamento presente no Estado, é apenas uma manifestação do "mal de arquivo" que quer tudo arquivar. Tanto a burocracia é voraz e quer reduzir tudo ao arquivável, como a mencionada historiografia tradicional quer reduzir o saber histórico ao arquivo. Os indivíduos modernos, como vimos, são arquivos que se dividem entre o acessível (consciente) e o secreto (inconsciente). Poderíamos também pensar na vida moderna e sua divisão entre o 
público e o privado. E, dentro do privado, podemos acrescentar a divisão entre a esfera familiar e a íntima. Os totalitarismos, com a onipresença do Estado (relatada tão bem em 1984 de Orwell), reduziram até essa esfera privada a quase nada. Tudo era arquivado pelo Estado com seu olho onividente. A própria esfera íntima era "estatizada." Mas agora as novas tecnologias estão embaralhando essas fronteiras de modo distinto. De início, oscilou-se entre duas possibilidades. Pensou-se que elas cumpririam o sonho de uma sociedade sem fronteiras, sem paredes, transparente, como já prometia a Bauhaus, com seus prédios de vidro (transparência comemorada por Benjamin e muitos vanguardistas). Por outro lado, acreditou-se (Flusser, por exemplo) que essas novas tecnologias permitiriam um encastelamento no mundo privado. Com o computador, na qualidade de terminal de mega-arquivos, aliada à sua capacidade de comunicação, não precisaríamos mais nos deslocar para nos informar. Tudo poderia ser acessado pelo monitor do computador. Pois bem, com a multiplicação dos terminais sob a forma de gadjets, os próprios terminais se tornaram nômades e sem lugar, ajudando a novamente romper as paredes das casas. Por outro lado, a transparência mostrou-se um tanto distópica. Na era do Face/Fakebook, ou seja, dos arquivos instantâneos do vivido (mas não da vida), assistimos a uma virada em nossa relação com o arquivamento privado. Essa aparente abertura da vida, que romperia as fronteiras do público e do privado, na verdade serve, como a moda flagrada e despida por Eijkelboom, para estandardizar e controlar a diferença. Vivemos cada momento da vida, sobretudo os encontros sociais e os momentos de entretenimento e de turismo, como uma oportunidade para criar belos "instantâneos de felicidade". Nossa vida se dá em função dessas imagens que apresentamos como a realização de uma vida bem sucedida. Só por aí já se percebe como a internet pode nos colonizar e controlar. Não bastasse isso, neste ano de 2013 reconhecemos como o ocidente também tem seu "big brother" que monitora via internet todos nossos passos e pensamentos. O arconte, o dono da chave da black box da internet, pode nos controlar como se fossemos todos habitantes de uma mesmo tribo - a "aldeia global."5 Os artistas anarquivadores querem roubar essa chave e democratizar esse arquivo. Eles praticam também um outro modo de escrita em si, avesso à glamourização acrítica da vida produzida nas redes sociais. É evidente que essas redes também têm um potencial de mudança da sociedade, mas ainda prepondera na rede a força do meio sobre seus usuários: ainda somos mais títeres da internet e dos gadjets, não o contrário. Como afirmava Vilém Flusser há 30 anos, precisamos impedir que os tecnocratas e o poder a que 
servem dominem o novo universo das imagens digitais. Devemos ocupar a internet, assim como revoltados no mundo todo vêm ocupando praças e manifestando sua revolta contra o governo internacional neoliberal. Solakov, com sua impressionante obra-arquivo, já nos fazia rever nossos novos sistemas digitais de arquivamento. Inúmeras obras, artísticas, literárias e híbridas, nos fazem refletir hoje sobre essas novas fronteiras entre o privado, o público e o íntimo.

A 55. Biennale di Venezia teve agora em 2013 por tema I/ Palazzo Enciclopedico. Com curadoria de Massimiliano Gioni, ela colocou a figura do arquivo em seu centro. Como imagem inicial emblemática foi eleita a obra // Enciclopedico Palazzo del Mondo, de Marino Auriti, um trabalho que reencarna no meio do século XX o teatro da memória de Giullio Camillo, um clássico da história da memória e da mnemotécnica. Não caberia aqui recordar os caminhos percorridos pela arte da memória na Idade Média, cujas marcas podem ser lidas tanto na topografia desenhada por Dante em sua Divina Comédia, como também nas catedrais (com sua arquitetura simbólica, seus nichos repletos de imagens da paixão de Cristo, mas também com suas inúmeras representações pictóricas da hierarquia celeste ou das virtudes cardinais), na poesia imagética e na prática dos acrósticos etc. A função didática e reprodutora de ideias e da visão de mundo eclesiástica das obras medievais representa um campo de estudos em si; por outro lado, a hibridização das palavras com imagens também respondia a um princípio básico da arte (leia-se: técnica) da memória. No Renascimento, essa tradição tem continuidade tanto em tratados de pura mnemotécnica como também em simples listas de imagines agentes (agentes imagéticos de memorização) e no desenvolvimento de alfabetos visuais. (YATES, 1974, p. 113) Um dos sonhos dos tratadistas da memória dessa época - representado de modo exemplar pelo teatro da memória de Giullio Camillo - era justamente conseguir reduzir todo o conhecimento macrocósmico em um conjunto de imagens (um microcosmo) que poderia ser assimilado por uma só pessoa, de tal modo que com um simples olhar sobre as imagens organizadas de um modo panóptico, poderíamos nos apropriar de todo esse saber. A verdade enquanto a-lethéia (termo grego para verdade que significa literalmente: não-esquecimento), tal como ela era pensada na tradição platônica, aliara-se de um modo anticlássico à doutrina da arte da memória.

Nessa Biennale várias obras retomam o gesto do anarquivamento e da recoleção. Ela tinha, por exemplo, obras da fotógrafa já mencionada Zanele Muholi. Nessa mesma linhagem do 
olhar feminino que desconstrói arquivos e poderes falocêntricos, podia-se ver a já famosa série de Linda Fregni Nagler (1976, Estocolmo), The Hidden Mother, 2006-2013, com centenas de imagens fotográficas do século XIX e início do século XX, nas quais as figuras maternas desaparecem, são escondidas por panos, caixas ou postas fora do campo da foto, e sustentam seus filhos que posam para a câmara fotográfica. Essas mães estão ao mesmo tempo presentes e ausentes e essa ambiguidade acaba trazendo à tona a própria figura feminina como recalcada na história. Mesmo que essas pessoas escondidas às vezes sejam o pai, ao batizar sua obra como The Hidden Mother, Linda Fregni Nagler faz uma afirmação política. Ela colecionou essas imagens para em sua apresentação anarquivá-las, mostrando algo de sinistro nessas figuras fantasmáticas, que manifestam o Unheimlich, o sinistro, trazem à tona recalques e violências arquivadas. O conceito freudiano de Unheimlich, de resto, deve ser visto como uma potente alavanca para a leitura dessas obras que desarquivam a intimidade. Elas são marcadas pela angústia da busca da "pátria", da Heimweh (saudades, em alemão, mas literalmente dor-do-lar ou dor-da-pátria), a saudade de uma completude, que todo arquivo paradoxalmente promete superar na mesma medida em que sela a impossibilidade de retorno à origem. ${ }^{6}$ Tendo a ver nessas obras contemporâneas uma encenação irônica (ou, às vezes, trágica) desse jogo ambíguo de superação da saudade e da sua impossibilidade.

Também em outras obras dessa Biennale muitas vezes o privado se torna público para relativizar essas fronteiras, como na vídeo-instalação de Dieter Roth (1930-1998), Solo Scenes, de 1998, ano de sua morte. Os 131 monitores de TV apresentam cenas cotidianas do artista em suas casas, onde o vemos lendo jornal, trabalhando na escrivaninha, indo ao toalete, caminhando por corredores etc. A mais pura banalidade se torna material de arquivo nesse desarquivamento da arte como coleção de "grandes feitos da história". Já a famosa série de Kohei Yoshiyuki (1946, Hiroshima), The Park (1971-1979), apresenta voyeurs nos parques de Tóquio flagrando encontros sexuais noturnos. Tornamo-nos, ao ver essas obras de Yoshiyuki, observadores de terceiro grau, pois o artista observava ele mesmo os observadores. Nessa telescopagem de voyeurismo novamente a intimidade é exposta, mas dessa vez dentro de uma estética do ilícito e do gozo. O "escondido" é publicizado e, nesse gesto, destabuizado. Ao abrir o arquivo da cena sexual noturna dos parques, Yoshiyuki também põe em discussão tabus em torno da sexualidade em uma sociedade repressora na qual as pessoas preferem 
fechar os olhos para essas cenas. Yoshiyuki deslouca também, a seu modo, o arquivo do parque. Por sua vez, Evgenij Kozlov (1955, de São Petersburgo), com seu enorme painel The Leningrad Album, 1967-1973, apresenta uma série de mais de 250 desenhos a nanquim e caneta, com imagens criadas por ele no final da adolescência, cheias de fantasias e de documentação de cenas sexuais envoltas em um ar de banal cotidianidade, que ele em parte testemunhou tendo sido criado em prédios comunitários, as Kommunalka. Essa série pode ser interpretada como uma espécie de diário da formação sexual de Kozlov, que frequentava livremente, ao lado da mãe, saunas femininas e a vida íntima cotidiana das mulheres no seu arredor. Essa exposição da fantasia erótica também vem acompanhada de boa dose de voyeurismo e de ironia diante dos tabus sexuais. Essa obra novamente coloca em questão as fronteiras entre os espaços onde a manifestação da sexualidade é ou não permitida e mostra reiteradamente como a arte contemporânea busca também abrir esse arquivo da intimidade sexual, do corpo como pulsão que se estende pelo campo da arte ao invés de ser domado e "sublimado". Todo arquivo tem algo de uma saudade da origem. Ele é suplemento, hupomnema. (DERRIDA, 2001, p. 22; FOUCAULT, 2004, p. 826) Ele quer ser a superação do Unheimlich que habita o sujeito moderno, com sua dialética aparentemente insuperável entre interior e exterior, eu e tu, privado e público, próprio e estrangeiro, consciente e inconsciente. Essas obras que lidam com o deambular das pulsões, sua atopia e não seu controle e submissão ao local correto, propõem heterotopias, novas geografias das pulsões. Mas essas proposições são abertas, não apresentam soluções fechadas e prontas. Permanecem como pura abertura, indicações de possibilidades.

Já o artista vietnamita Danh Vo, nessa mesma Biennale, levou uma igreja católica de 200 anos, do Vietnan, para Veneza. Esse deslocamento, essa transposição de arquivo, serve para resignificá-lo, abalá-lo em seu sentido colonialista original. O artista agora pode como que abrir uma visada crítica sobre o arquivo da colonização, material e espiritual, que o Vietnam foi vítima durante séculos. Sua obra apresenta a estrutura dessa igreja e veludos que portavam obras de arte sacra, que deixaram apenas sua marca no veludo, desbotado pela exposição à luz. Essas inscrições de luz, que lembram o princípio dos fotogramas de um Man Ray e de Moholy-Nagy, apontam para arquivos desaparecidos, são traços que precisam ser lidos e preenchidos de sentido. O vazio acaba sendo a mensagem predominante desse anarquivamento. ${ }^{7}$ 
Essas obras de arte e suas leituras que apresentei aqui devem ser vistas como uma tentativa de propor a figura do arquivo como uma chave para organizarmos o que se passa na nossa cultura hoje. O discurso sobre o arquivo se desdobra a partir de três estruturas principais: o Estado, nossa psique e nosso corpo. Esse olhar arquival sobre a cultura, resumo aqui, tem portanto diversas origens. Em termos mais remotos esse olhar pode ser retraçado à história da arte da memória (nos termos da mnemotécnica, tal como Frances Yates nos reatualizou em meados do século XX, na senda aberta por Aby Warburg8). Mais próximo de nós, os arquivos foram instituições centrais nos Estados modernos e contemporâneas ao triunfo do historicismo com seu "excesso de história" criticado por Nietzsche. No século XX, o derretimento do arquivo central da razão ocidental serviu para desencadear um trabalho de rememoração e recoleção dos arquivos e de suas histórias. A psicanálise descreveu nosso ser onto- e filogenético como uma história de inscrição e recalcamento de arquivos. A virada biológica, por sua vez, entronizou a noção de herança genética e de processo de reinscrição de arquivos herdados. Já a virada cibernética generalizou discursos sobre memórias, arquivos, gravação e apagamento de informações e tudo que se relaciona à ideia de armazenamento do saber e dos fatos. Os atuais escândalos acerca da espionagem na internet, feita por países como os EUA, a Inglaterra e Canadá, dão agora um tom paranoico e apocalíptico à nossa era de arquivos digitais on-line. Os artistas, nessa paisagem, vêm pensando, desde o romantismo, contra-estratégias diante da arquivação e arquivonomia monológicas. Eles propõe a abertura desses arquivos, sua anarquivação, e assim abrem novos horizontes, hoje, para que nos apropriemos de arquivos de modo criativo e antifascista. Assim eles subvertem os arquivos e seu logos com uma ação estético-política. Se nas primeiras palavras do Evangelho de São João lemos que "No princípio foi o verbo", "En archē ēn ho Lógos", ou seja, na nossa origem, na nossa arché primeira, teria se feito valer a palavra, com Goethe e sua reversão faustica desse dito, podemos declarar, como mote desses artistas anarquivadores, "Im Anfang war die Tat" 9 : "No início foi o ato." Eles querem ir além do porteiro do arquivo, do arconte, e se apropriar criativamente, recolecionando as informações do arquivo. A figura passiva do camponês, da conhecida parábola de Kafka Diante da lei, deve ser substituída pelo artista ativo que não se submete aos ditames e ameaças do porteiro e, finalmente, adentra à lei. 


\section{Notas}

1 Apud BENJAMIN, 1989, p. 78. Com relação às semelhanças deste procedimento do catador com o trabalho do próprio Benjamin, cf. este fragmento do seu livro sobre as passagens de Paris: "Método deste trabalho: Montagem literária. Eu não tenho nada a dizer. Apenas a mostrar. Eu não vou furtar nada de valioso ou apropriar-me de formulações espirituosas. Mas sim os trapos, o lixo: eles eu quero não inventariar, mas, antes, fazer justiça a eles do único modo possível: utilizando-os". (BENJAMIN, 1982, p. 574) No livro de Benjamin sobre o drama barroco alemão os conceitos de alegoria e de melancolia são articulados ao desejo barroco de armazenamento das coisas e ruínas do mundo. (Cf. SELIGMANN-SILVA, 2005, p. 123-140) Com relação à dialética entre o alegorista e o colecionador, ver também Benjamin (1982, p. 279).

2 Cf. também um aforismo de seu Einbahnstrasse (Rua de mão única): "CRIANÇA DESORDEIRA. Cada pedra que ela encontra, cada flor colhida e cada borboleta capturada já é para ela princípio de uma coleção única. Nela esta paixão mostra a sua verdadeira face, o rigoroso olhar índio, que, nos antiquários, pesquisadores, bibliômanos, só continua ainda a arder turvado maníaco. Mal entra na vida, ele é caçador. Caça os espíritos cujo rastro fareja nas coisas; entre espíritos e coisas ela gasta anos, nos quais seu campo de visão permanece livre de seres humanos." (BENJAMIN, 1987, p. 39) Lembremos de Bispo, que cada vez mais se isolou entre os objetos de sua coleção do mundo.

3 Cf. os dois catálogos Marcelo Brodsky, 2000 e 2001, onde o leitor pode se informar sobre suas múltiplas produções, entre as quais suas obras em torno das ruínas da AMIA (a Asociación Mutua Israelita Argentina da rua Pasteur em Buenos Aires, que sofreu o atentado terrorista em 18 de julho de 1994, deixando 84 mortos), bem como seu engajamento na construção do "Parque de la Memoria" em Buenos Aires.

4 Apesar de muito conhecida, vale a pena lembrar dessa tese aqui: "Há um quadro de Klee que se chama Angelus Novus. Nele está desenhado um anjo que parece estar na iminência de se afastar de algo que ele encara fixamente. Seus olhos estão escancarados, seu queixo caído e suas asas abertas. $\mathrm{O}$ anjo da história deve ter esse aspecto. Seu semblante está voltado para o passado. Onde nós vemos uma cadeia de acontecimentos, ele vê uma catástrofe única, que acumula incansavelmente ruína sobre ruína e as arremessa a seus pés. Ele gostaria de deter-se para acordar os mortos e juntar os fragmentos. Mas uma tempestade sopra do paraíso e prende-se em suas asas com tanta força que o anjo não pode mais fechá-las. Essa tempestade o impele irresistivelmente para o futuro, ao qual ele volta as costas, enquanto o amontoado de ruínas diante dele cresce até o céu. É a essa tempestade que chamamos progresso". (BENJAMIN, 2012, p. 245s)

5 Marshall McLuhan formulou o conceito de global village que Flusser comentou ironicamente em 1985: "O que McLuhan chamou, de maneira otimista, de 'aldeia cósmica', será uma massa de indivíduos solitários unidos entre si pela identidade cósmica dos programas". (FLUSSER, 2008, p. 56)

6 O ensaio de Freud O estranho (Das Unheimlich), de 1919, é uma peça chave na sua busca de compreensão dos mecanismos do inconsciente. O "estranho" é discutido a partir tanto de uma passagem de Schelling (segundo a qual Unheimlich "denomina-se tudo aquilo que deveria ter ficado escondido, mas veio à tona"), como de contos fantásticos de E.T.A. Hoffmann. Ele manifestaria aquilo que está como que enterrado, foi censurado e recalcado em nosso inconsciente. Dois dos elementos mais evidentes dentre estes corpos enterrados em nós, são a morte e o complexo de castração, com a angústia ligada a este complexo. Outro exemplo de Freud é o útero materno e o corpo da mãe: um corpo que nos foi familiar e depois virou "unheimlich", sendo que este "un" é a marca do recalcamento. (FREUD, 1970, p. 267) Em fenômenos estéticos ou na vida real que provocam o sentimento de "estranho", manifesta-se 
esta "compulsão à repetição" que é a marca destes elementos recalcados que querem voltar à luz do dia. Este texto foi fundamental para a análise que Freud depois faria, no ano seguinte, em Para além do princípio do prazer, de nossa psicologia como um campo de tensão entre Eros e Tânatos. Acredito que o conceito de Unheimlich deve servir como uma das chaves para entendermos nosso "mal de arquivo".

7 É importante notar também que uma das principais obras da Biennale de 2013 foi o livro com a versão em história em quadrinhos da Gênesis, de Robert Crumb. O livro estava reproduzido em sua íntegra em meio à exposição. Crumb realiza nessa obra uma impactante releitura da primeira parte do livro dos livros, a Bíblia, essa arca que traz de uma distância de milênios um arquivo que vem sendo incessantemente reinterpretado por artistas e reescrito. Crumb, com sua tradução intersemiótica (ou intermidiática) livre e muito criativa, realiza um impressionante tour de force e atualiza de modo brutal, como no gesto do colecionador benjaminiano, o arquivo bíblico, que sofre sob o peso da tendência à cooptação pela teologia, pela religião e pela filologia, verdadeiras porteiras da Bíblia.

8 Lembro aqui do projeto Mnemosyne de Warburg (2003), que o acompanhou nos últimos anos de sua vida, que justamente propunha um recolecionamento da história da arte, contra os arquivamentos feitos em pastas calcadas seja em eras ou em estilos, como ocorria desde Winckelmann.

9 Goethe, Faust, $1^{\text {a. }}$ parte, $3^{\text {a. }}$ cena. Essa frase foi citada por Freud no final de seu Totem e tabu, servindo como chave para sua conclusão, a saber, que o assassinato do pai da horda primeva de fato aconteceu. (FREUD, 1993, p. 444)

\section{Referências}

BENJAMIN, Walter. Obras escolhidas - Magia e Técnica, Arte e Política, vol. I. Trad. J.C.M. Barbosa e H.A. Baptista. 8a. ed. São Paulo: Brasiliense, 2012. (revisada por M. Seligmann-Silva)

BENJAMIN, Walter.Obras escolhidas, v. III, Charles Baudelaire, um lírico no auge do capitalismo. Trad. J.C.M. Barbosa e H.A. Baptista. São Paulo: Brasiliense, 1989.

BENJAMIN, Walter. Das Passagen-Werk. In: BENJAMIN, Walter. Gesammelte Schriften, vol. V (org. R. Tiedemann e H. Schweppenhäuser). Frankfurt: Suhrkamp, 1982.

BENJAMIN, Walter. Gesammelte Schriften, vol. IV (org. R. Tiedemann e H. Schweppenhäuser). Frankfurt: Suhrkamp, 1972.

BRODSKY, Marcelo, Buena memoria. Un ensayo fotográfico de Marcelo Brodsky. Roma, 2000.

BRODSKY, Marcelo, Nexo. Un ensayo fotográfico. Buenos Aires: La Marca, 2001.

DERRIDA, Jacques. Mal de arquivo. Uma impressão freudiana. Trad. C. de Moraes Rego. Rio de Janeiro: Relume Dumará, 2001.

FLUSSER, Vilém, O universo das imagens técnicas. Elogio da superficialidade. São Paulo: Anna Blume, 2008.

FOUCAULT, Michel. L'écriture de soi; Les techniques de soi, In: FOUCAULT, Michel. Philosophie, Antropologie (org. Arnold Davidson e Frédéric Gros). Paris: Gallimard, 2004, p. 822-57.

FREUD, S., Das Unheimlich, In: FREUD, S.. Freud-Studienausgabe, vol. IV. Frankfurt/M.: Fischer Verlag, 1970, p. $241-274$.

FREUD, S. Totem und Tabu. Einige Übereinstimmungen im Seelenleben der Wilden und der Neurotiker. In: Studienausgabe. Fragen der Gesellschaft, Ursprünge der Religion, Frankfurt/M.: S. Fischer, 1993, p. 287-444. 
FREUD, S. Totem e tabu. Trad. Ô. Muniz. Rio de Janeiro: Imago, 1999.

GERZ, Jochen. La question secrète. Biron. Arles: Actes du Sud, 1996.

NIETZSCHE, F.. Unzeigemässe Betrachtungen II: Vom Nutzen und Nachteil der Historie für das Leben. In: Kritische Studienausgabe (org. G. Colli e M. Montinari). München: DTV/ Berlin-New York: Walter de Gruyter, 1988.

MAUSS, Marcel. Ensaios sociológicos. Trad. L. Gaio e J. Guinsburg. 2ª ed. S. Paulo: Perspectiva, 1999.

RAMOS, Nuno. 111. São Paulo: Gabinete de Arte Raquel Arnaud, 1993.

SALMON, Naomi Tereza. Asservate. Exhibits. Auschwitz, Buchenwald, Yad Vashem, Frankfurt/M.: Schirn Kunsthalle / Cantz Verlag, 1995.

SELIGMANN-SILVA, Márcio. Walter Benjamin e os Sistemas de Escritura. In: SELIGMANN-SILVA, Márcio. O local da diferença. Ensaios sobre memória, arte, literatura e tradução. São Paulo: Editora 34, 2005, p. 123-140.

SELIGMANN-SILVA, Márcio, Fotografia como arte do trauma e imagem-ação: Jogo de espectros na fotografia de desaparecidos das ditaduras na América Latina. Temas em Psicologia, v. 17, n. 2, 311-328, 2009.

WARBURG, Aby. Der Bilderatlas Mnemosyne, editado por Martin Warnke. Berlin: Akademie Verlag, 2003. (Gesammelte Schriften, segunda seção, vol. II.1)

YATES, Frances A. Art of memory. University of Chicago Press, 1974. (A arte da Memória. Trad. Flávia Bancher. Campinas: Editora da UNICAMP, 2008.) 